\title{
PENGARUH ADVERSITY QUOTIENT DAN MOTIVASI BEPRESTASI TERHADAP KINERJA PENDIDIK PAUD DITINJAU DARI KELOMPOK ETNIS
}

\author{
Widya Ayu Puspita*
}

\begin{abstract}
The early childhood teacher is expected to be able to to do his/her best in educating ealy age children if he/she has high adversity quotient, This research aimed to explore the influence of adversity intelegence and achievement motivation to early childhood teacher performance. There are 94 respondents participated in this study, age 20 - 40 years old. The data were collected using three instruments, those are Adversity Respons Profile (ARP) Quick Take, Achievement Motivation scale and performance scale. Data was analyzed by two ways anova, dummy linier regression and independent t-test.This research concludes that adversity quotient and motivation influence the performance, but ethnic is only moderaor variables. there is no difference in AQ between Java and Maduresse, but there is a difference on motivation score between Java and Maduresse.
\end{abstract}

Key words : adversity quotient, achievement motivation, teacher's performance, ethnic group.

\begin{abstract}
Pendidik Pendidikan Anak Usia Dini diharapkan dapat melaksanakan tugasnya sebaik-baiknya dalam mendidik anak usia dini, apabila ia memiliki Adversity Quotient (AQ) yang tinggi. Penelitian ini bermaksud mengkaji pengaruh $A Q$ dan motivasi berprestasi terhadap kinerja guru Pendidikan Anak Usia Dini. Penelitian ini mengikutsertakan 94 responden dengan usia antara 20-40 tahun. Data dikumpulkan dengan menggunakan tiga instrumen, yaitu Adversity Response (ARP) Quick Take, skala Achievement Motivation, dan skala kinerja. Data dianalisis dengan menggunakan anova dua jalur, regresi linier, dan t-test independen. Penelitian ini menyimpulkan bahwa $A Q$ dan motivasi mempengaruhi kinerja, tetapi faktor etnis hanya berperan sebagai variabel moderator. Tidak terlihat perbedaan AQ antara orang Jawa dan Madura, akan tetapi terdapat perbedaan motivasi antara orang Madura dan Jawa.
\end{abstract}

Kata-kata kunci: adversity quotient, motivasi berprestasi, kinerja guru, etnis.

\section{PENDAHULUAN}

\section{Latar Belakang}

Pendidikan Anak Usia Dini (PAUD) merupakan upaya pembinaan dan pengasuhan yang ditujukan kepada anak sejak lahir hingga usia 6 tahun, meskipun sesungguhnya akan lebih optimal lagi apabila ditujukan kepada anak sejak dalam kandungan hingga usia 8 tahun. Pendidikan bagi anak usia dini dilakukan melalui pemberian rangsangan pendidikan untuk membantu pertumbuhan dan perkembangan jasmani dan rohani agar anak memiliki kesiapan dalam memasuki pendidi-

* Pamong Belajar BPPNFI Regional IV kan lebih lanjut. Tujuannya adalah membantu mengembangkan seluruh potensi dan kemampuan fisik, intelektual, emosional, moral dan agama secara optimal dalam lingkungan pendidikan yang kondusif, demokratis dan kompetitif.

PAUD merupakan komitmen dunia. Jomtien Thailand (1990) menghasilkan komitmen 'Pendidikan untuk semua orang, sejak lahir sampai menjelang ajal', sedangkan Deklarasi Dakkar (2000) menghasilkan komitmen 'Memperluas dan memperbaiki keseluruhan perawatan dan Pendidikan Anak Usia Dini secara komprehensif terutama yang sangat rawan dan terlantar' dan Deklarasi "A World Fit For Children" di New York 
(2002) yang menghasilkan komitmen 'Penyediaan Pendidikan yang Berkualitas'.

Pendidikan Anak Usia Dini dalam hal ini memegang posisi strategis dalam upaya meningkatkan kesejahteraan anak usia dini, yang berada dalam periode keemasan (golden period). Dalam pelaksanaan Pendidikan Anak Usia Dini, berbagai pihak memiliki peranan yang sangat penting, terutama orangtua sebagai pihak terdekat anak dalam pendidikan keluarga. Sementara itu, dalam Pendidikan Anak Usia Dini yang diselenggarakan oleh lembaga pendidikan, pendidik PAUD merupakan ujung tombak di lapangan, karena berhubungan langsung dengan anak-anak dan seringkali pula dengan orangtua.

Pada era globalisasi, pendidik PAUD menghadapi banyak sekali tuntutan, baik dari lembaga, masyarakat, pengambil kebijakan, maupun orangtua. Tuntutan ini sedikit banyak berkaitan dengan standar profesional dan kualifikasi yang seringkali belum dapat terpenuhi. Memenuhi standar profesi berarti telah memenuhi standar kompetensi dan karakter tuntutan kerja. Persoalan kompetensi yang harus terpenuhi harus diiringi oleh daya juang atau tahan banting dan semangat kerja, yang akhirnya akan menentukan kinerja pendidik PAUD. Tuntutan sikap profesional dalam PAUD juga merupakan suatu proses seleksi bagi pendidik PAUD untuk tetap bisa mempertahankan profesi yang tengah dijalaninya.

Dalam pengembangan kelembagaan dan sumber daya manusia yang handal dalam PAUD, potensi personal selalu dipertimbangkan untuk meningkatkan kinerja pendidik PAUD secara individu. Kinerja individu akan mendukung kinerja lembaga yang dampaknya akan terlihat pada prestasi dan kemajuan lembaga atau organisasi. Potensi inilah yang akan diolah menjadi energi untuk menyumbangkan target yang dicanangkan oleh lembaga. Potensi personal sangat beragam, dari mulai kemampuan intelektual atau kognisi yang sering dinotasikan sebagai tingkat Intelegence Quotient (IQ), sikap kerja, emosi, dan hubungan sosial sering dinotasikan sebagai tingkat Emotional Quotient (EQ), sampai dengan kemampuan psikologis-spiritual, antara lain sikap kerja, emosi, dan hubungan sosial yang sering dinotasikan sebagai tingkat Emotional Spiritual Quotient (ESQ).

Pada akhirnya terjadilah perkembangan teori yang membahas tentang penentu sukses tidaknya seseorang dalam menghadapi dunia kerja, yang disebut Adversity Quotient (AQ) atau sering disebut kecerdasan adversity. AQ diperkenalkan oleh Stoltz (2000) sebagai faktor penentu kesuksesan seseorang dalam mengha- dapi tantangan dalam pemasalahan hidup yang dihadapi.

Uraian di atas menunjukkan bahwa apabila kita menginginkan kehidupan yang penuh dengan prestasi, maka hendaklah memiliki $A Q$ yang tinggi, sehingga mampu menghadapi setiap permasalahan yang ada. Hal ini berlaku pula bagi pendidik dan tenaga kependidikan pendidikan non formal, khususnya pendidik PAUD yang sehingga dihadapkan pada berbagai permasalahan yang kompleks.

Apabila pendidik PAUD memiliki AQ yang tinggi, maka dia akan mampu mengatasi setiap permasalahan yang muncul dan bahkan berupaya mencapai prestasi tertinggi dalam pengembangan PAUD. Di sisi lain, apabila pendidik PAUD memiliki AQ yang kurang, akan cepat mengalami putus asa dan frustasi, yang berakibat pada rendahnya kinerja dalam mendidik anak. Rendahnya kinerja ini dapat mempengaruhi proses pendidikan terhadap anak, sehingga menyebabkan kurang optimalnya layanan bagi anak.

Penelitian ini hendak mengeksplorasi adversity quotient (kecerdasan adversity) pendidik PAUD di salah satu kabupaten yang ada di Propinsi Jawa Timur, yaitu Kabupaten Bondowoso. Penelitian ini akan mengkaji pengaruh antara adversity quotient dan motivasi berpretasi terhadap kinerja pendidik PAUD. Untuk peng-kajian tersebut, akan dibedakan atas kelompok etnis, karena kelompok etnis yang berbeda akan membawa budaya kerja yang berbeda, sehingga adversity quotient, motivasi berprestasi dan kinerja dimungkinkan berbeda antar etnis. Etnis di sini dimaksudkan adalah suku bangsa pendidik PAUD yang ada di Kabupaten Bondowoso, meliputi Jawa dan Madura.

Dari hasil penelitian ini diharapkan didapatkan gambaran mengenai adversity quotient pendidik PAUD di Kabupaten Bondowoso, sehingga dapat dilakukan upaya-upaya perbaikan yang diperlukan, guna senantiasa meningkatkan kinerja pendidik PAUD dalam memberikan layanan bagi anak.

\section{Rumusan Masalah}

1. Apakah kecerdasan adversity dan motivasi berprestasi secara simultan berpengaruh terhadap kinerja pendidik PAUD di Kabupaten Bondowoso?

2. Apakah kecerdasan adversity dan motivasi berprestasi secara parsial berpengaruh terhadap kinerja pendidik PAUD di Kabupaten Bondowoso?

3. Apakah tingkat kecerdasan adversity dan tingkat motivasi berprestasi berbeda berdasarkan kelompok etnis pendidik PAUD di Kabupaten Bondowoso?

\section{Tujuan Penelitian}


1. Menganalisis pengaruh kecerdasan adversity dan motivasi berprestasi secara simultan terhadap kinerja pendidik PAUD di Kabupaten Bondowoso.

2. Menganalisis pengaruh kecerdasan adversity dan motivasi berprestasi secara parsial terhadap kinerja pendidik PAUD di Kabupaten Bondowoso.
3. Menganalisis perbedaan tingkat kecerdasan adversity dan tingkat motivasi berprestasi berdasarkan pendidik PAUD di Kabupaten Bondowoso.

\section{KAJIAN TEORETIS}

\section{Pendidikan Anak Usia Dini (PAUD)}

Pendidikan Anak Usia Dini telah berkembang luas, baik di negara maju maupun di negara yang sedang berkembang. Berbagai macam program Pendidikan Anak Usia Dini ini dikembangkan oleh pemerintah, swasta maupun masyarakat. Minat mengembangkan Pendidikan Anak Usia Dini sesungguhnya bersumber dari lima macam pemikiran yaitu tuntutan, persaingan global, pentingnya peng-asuhan yang tepat, keinginan untuk meningkatkan kualitas anak dan dampak positif Pendidikan Anak Usia Dini dalam jangka panjang (Mitchell, 2005).

Pendidikan Anak Usia Dini menekankan pada pentingnya partisipasi aktif orangtua dan masyarakat, karena hal ini penting artinya bagi perkembangan anak secara optimal. Ada tiga kemungkinan keterlibatan orang tua pada Pendidikan Anak Usia Dini, yaitu orientasi pada tugas, orientasi pada proses, dan orientasi pada perkembangan.

Bentuk keterlibatan yang paling ideal adalah segala sesuatu yang mencakup keterlibatan yang berorientasi tugas, proses dan perkembangan. Dengan demikian, keterlibatan ini bersifat menyeluruh, sehingga anak dapat tumbuh dan berkembang secara optimal.

Pendidikan Anak Usia Dini sesungguhnya merupakan bagian integral dalam Sistem Pendidikan Nasional yang saat ini mendapat perhatian cukup besar dari pemerintah. Konsep pendidikan bagi anak usia dini merupakan adopsi dari konsep Early Child Care and Education (ECCE) yang juga merupakan bagian dari Early Child Development (ECD). Konsep ini membahas upaya peningkatan kualitas sumber daya manusia dari sektor "hulu", sejak anak usia 0 tahun bahkan sejak pra lahir hingga usia 8 tahun.

Oleh karena itu, teori lama yang merekomendasikan bahwa pendidikan baru dapat dimulai ketika anak telah berusia 7 tahun, kini terbantahkan. Hasil penelitian mutakhir dari para ahli neurologi, psikologi, dan paedagogi menganjurkan pentingnya pendidikan dilakukan sejak anak dilahirkan, bahkan sejak anak masih dalam kandungan ibunya. Justru pada masa-masa awal inilah yang merupakan masa emas (golden age) perkembangan.

Hasil penelitian menunjukkan bahwa 50\% kapabilitas kecerdasan manusia terjadi pada tingkat kanakkanak pada kurun waktu 4 tahun pertama sejak kelahirannya. Oleh karena itu penanganan anak dengan stimulasi pendidikan pada masa-masa usia tersebut harus optimal. Kemudian, 80 persen kecerdasan itu terjadi saat anak usia 8 tahun, dan titik kulminasinya saat mereka berusia 18 tahun. Setelah melewati masa perkembangan tersebut, maka berapa pun kapabilitas kecerdasan yang dicapai oleh masing-masing individu, tidak akan meningkat lagi.

Semua aspek perkembangan kecerdasan anak, baik motorik kasar, motorik halus, kemampuan non fisik, dan kemampuan spiritualnya dapat berkembang secara pesat apabila memperoleh stimulasi lingkungan secara cukup. Perkembangan yang terjadi pada masa ini sangat berpengaruh terhadap perkembangan anak selanjutnya.

\section{Konsep Adversity Quotient}

Adversity quotient diperkenalkan pertama kali oleh Stoltz (2000) ke dalam tiga bentuk. Pertama, merupakan suatu kerangka kerja konseptual yang baru untuk memahami dan meningkatkan semua segi kesuksesan, kedua merupakan suatu ukuran untuk mengetahui respon seseorang terhadap kesulitan dan ketiga, merupakan serangkaian peralatan yang memiliki dasar ilmiah untuk memperbaiki respon seseorang terhadap kesulitan.

Secara konseptual, adversity quotient menurut WHO mempunyai pengertian kesanggupan seseorang untuk tetap memelihara integritas dirinya ketika berada dalam situasi adanya ancaman, gangguan, hambatan dan tantangan. Adversity quotient dapat pula diungkapkan melalui apa yang dipunyai atau tidak dipunyai oleh individu, misalnya kekuatan ego, harga diri dan keluhan fisik yang dimiliki individu. Lebih lanjut dikatakan bahwa sesorang yang mempunyai kekuatan ego yang tinggi akan terhindar dari gangguan mental, sehingga dapat diartikan bahwa tingkat ketahanan mentalnya tinggi pula. 
Dengan demikian dapat disimpulkan bahwa adversity quotient merupakan ketahanan mental yang dimiliki seseorang dalam menghadapi kesulitan untuk bertahan hidup dan bagaimana keterampilan tersebut dapat menjadikan seseorang mampu menemukan jalan keluar dan bertahan ketika harus menghadapi kesulitan atau masalah, bahkan bisa menjadikan kesulitan sebagai tantangan sekaligus sebagai peluang.

Di dalam merespon suatu kesulitan untuk mencapai kesuksesan dan kebahagiaan terdapat tiga kelompok tipe manusia ditinjau dari tingkat kemampuannya yaitu quitters, campers dan climbers (Stoltz, 2000).

Quitters atau mereka yang berhenti adalah seseorang yang memilih untuk keluar, menghindari kewajiban, mundur dan berhenti apabila menghadapi kesulitan. Campers atau mereka yang berkemah adalah orang-orang yang pernah mencoba menyelesaikan suatu kesulitan dan sekurang-kurangnya telah menanggapi tantangan pendakian yang ada, namun individu tersebut akan berhenti ketika menganggap masalah tersebut telah diselesaikan pada tingkat tertentu. Orang-orang ini lebih baik dibanding quitters, sekurangkurangnya bisa melihat dan merasakan tantangan. Climbers atau si pendaki adalah sebutan bagi mereka yang merasa terus perlu mencari alternatif solusi yang tepat. Climbers merupakan pemikir yang selalu memikirkan kemungkinan-kemungkinan. Ada empat dimensi untuk memahami aspek penting cara seseorang mengungkapkan adversitynya (Stoltz, 2000) yaitu control atau kendali, origin-ownership atau tanggung jawab, reach atau jangkauan dan endurance atau daya tahan. Kendali diawali dengan pemahaman bahwa sesuatu dan apapun itu dapat dilakukan. Origin atau asal usul mempertanyakan siapa atau apa yang menjadi asal usul kesulitan yang sering dikaitkan dengan rasa bersalah. Ownership lebih mencerminkan tanggung jawab.

Jangkauan mempertanyakan sejauh manakah kesulitan akan menjangkau bagian-bagian lain dari kehidupan seseorang. Membatasi jangkauan kesulitan merupakan hal yang sangat diharapkan. Semakin jauh seseorang membiarkan kesulitan itu mencapai wilayahwilayah lain dalam kehidupannya maka seseorang itu akan semakin merasa tidak berdaya dan kewalahan. Reach adalah sejauhmana kesulitan akan mempengaruhi bagian-bagian lain dari kehidupan seseorang. Pada reach seseorang akan menampilkan sikap sesuai dengan suasana hati. Jika seseorang tidak terpengaruh dengan tingkat kesulitan atau pandai memilah-milah jenis kesulitan tentu seseorang akan berperilaku wajar. Dimensi endurance mempertanyakan seberapa lama kesulitan akan berlangsung dan seberapa lama penyebab kesulitan akan berlangsung. Daya tahan seseorang terhadap kesulitan, akan berusaha mengurai kesulitan tersebut.

\section{Motivasi Berprestasi}

Menurut teori kebutuhan untuk mencapai prestasi yang dikemukakan oleh Clelland (dalam Munandar, 2001) adalah bahwa seseorang mempunyai cadangan energi potensial. Artinya bagaimana energi ini dilepaskan dan digunakan tergantung pada kekuatan dorongan motivasi seseorang dan situasi serta peluang yang tersedia. Energi ini akan termanfaatkan karena didorong oleh kekuatan motif dan kebutuhan dasar yang terlibat, harapan keberhasilan, dan nilai insentif yang terlekat pada tujuan. Dorongan yang kuat untuk berhasil, lebih mengejar prestasi pribadi daripada imbalan terhadap keberhasilan dan melakukan sesuatu lebih baik dan lebih efisien dibandingkan hasil sebelumnya yang disebut kebutuhan untuk berprestasi (need for achievement $=\mathrm{nAch}$ ).

Clelland (dalam Prabu, 2005) menge-mukakan bahwa seseorang dengan dorongan prestasi yang lebih tinggi berbeda dari orang lain dalam keinginan kuat untuk melakukan hal-hal dengan lebih baik. Mereka mencari kesempatan-kesempatan di mana mereka memiliki tanggung jawab pribadi dalam menemukan jawaban terhadap masalah. Mereka yang memiliki kebutuhan untuk berprestasi yang tinggi akan memperoleh umpan balik atas tugas pekerjaannya yang memiliki risiko yang sedang (moderate). Mereka bukan pemain judi (gambler), mereka tidak suka berhasil secara kebetulan. Tujuan-tujuan yang ditetapkan merupakan tujuan yang tidak terlalu sulit dicapai dan juga bukan tujuan yang terlalu mudah dicapai.

Clelland (dalam Winardi, 2002) merumuskan kebutuhan akan prestasi sebagai keinginan untuk melaksanakan sesuatu tugas atau pekerjaan yang sulit. Orang yang termotivasi untuk berprestasi, memiliki tiga macam ciri umum. Pertama, sebuah preferensi untuk mengerjakan tugas-tugas dengan derajat kesulitan moderat. Kedua, orang yang berprestasi tinggi juga menyukai situasi-situasi di mana kinerjanya timbul karena upaya-upayanya sendiri, dan bukan karena faktor-faktor lain, seperti misalnya kemujuran. Ketiga, mengidentifikasi yang berprestasi tinggi adalah yang menginginkan lebih banyak umpan balik tentang keberhasilan dan kegagalan dibandingkan dengan yang berprestasi rendah. Manifestasi dari motivasi berprestasi akan terlihat pada beberapa ciri perilaku seperti: (1) mengambil tanggung jawab pribadi atas perbuatanperbuatannya; (2) mencari umpan balik tentang perbuatannya; (3) memilih risiko yang moderat atau sedang dalam perbuatannya; dan (4) berusaha melakukan sesuatu dengan cara-cara baru dan kreatif. 
Selain dari aspek penting dalam motivasi berprestasi tersebut di atas, Mc. Clelland juga menjelaskan bahwa penelitian tentang kebutuhan berprestasi dalam kebanyakan kasus dipengaruhi oleh psikososial dan gender atau jenis kelamin. Diungkapkan bahwa struktur masyarakat dengan polamemberikan nilai lebih pada pencapaian prestai indi-vidu, motivasi secara umum, dan mengarahkan orang lain, sementara wanita lebih menekankan hubungan interpersonal yang baik, pekerjaan yang nyaman dan menarik, perasaan telah menyelesaikan sesuatu dan pertumbuhan profesional secara layak (Gibson et all, 1996:203).

\section{Kinerja}

Pengertian kinerja menurut kamus besar bahasa Indonesia (1993) adalah (1) sesuatu yang dicapai, (2) prestasi yang diperlihatkan, dan (3) kemampuan kerja. Dalam kamus online Wikipedia Indonesia, kinerja adalah sebuah kata dari kata dasar kerja yang berasal dari bahasa asing yang berarti prestasi atau bisa pula berarti hasil kerja. Berikut arti kinerja yang diuraikan oleh kamus online Wikipedia. Kinerja merupakan kombinasi dari kemampuan, usaha dan kesempatan yang dapat dinilai dari hasil kerjanya (Sulistiani, 2007). Kinerja atau prestasi kerja adalah hasil kerja yang dicapai seseorang pekerja dalam melaksanakan tugastugas yang dibebankan kepadanya yang didasarkan atas kecakapan, pengalaman dan kesungguhan serta waktu pencapaiannya.

Kinerja adalah pelaksanaan fungsi-fungsi yang dituntut dari seseorang, sehingga kinerja adalah sebuah perbuatan, suatu prestasi, suatu pameran umum keterampilan. Secara lebih spesifik, kinerja adalah penilaian terhadap seseorang yang telah bekerja dibandingkan dengan target yang telah ditetapkan. Sementara Mink (1989) mengemukakan pendapatnya bahwa individu yang memiliki kinerja yang tinggi memiliki beberapa karakteristik yaitu (a) berorientasi pada prestasi, (b) percaya diri, (c) mempunyai pengendalian diri dan (d) kompetensi.

Kinerja adalah pengalihbahasaan kata bahasa Inggris "performance". Bernardin dan Russel (dalam Ruky, 2001) memberikan definisi tentang performance sebagai berikut: "performance is devined as the record of outcomes produced on a specified job function or activity during a specified time period (digambarkan sebagai catatan dampak yang dihasilkan atas aktivitas atau fungsi pekerjaan tertentu selama suatu periode waktu yang ditentukan)". Dalam definisinya, kedua penulis tersebut menekankan pengertian prestasi sebagai "hasil" atau "apa yang keluar" (outcomes) dari sebuah pekerjaan dan kontribusinya pada organisasi. Seiring dengan ini, Dharma (1985) berpendapat prestasi kerja adalah sesuatu yang dikerjakan atau produk/jasa yang dihasilkan atau diberikan oleh seseorang atau sekelompok orang.

Mangkunegara (1999) mendefinisikannya kinerja sebagai berikut. Kinerja (performance) adalah hasil kerja yang dapat dicapai oleh seseorang atau sekelompok orang dalam suatu organisasi, sesuai wewenang dan tanggung jawab masing-masing dalam rangka upaya mencapai tujuan organisasi bersangkutan secara legal, tidak melanggar hukum dan sesuai dengan moral dan etika. Irawan (2002) mengartikan kinerja sebagai hasil kerja seorang pekerja, sebuah proses manajemen atau suatu organisasi secara keseluruhan, di mana hasil kerja tersebut harus dapat ditunjukkan buktinya secara konkrit dan dapat diukur (dibandingkan dengan standar yang telah ditentukan). Kata kunci kinerja menjadi hasil kerja pekerja, proses atau organisasi, terbukti secara konkrit, dapat diukur, dan atau dibandingkan dengan standar yang telah ditentukan.

Prabu (2005) menjelaskan bahwa kinerja seseorang dipengaruhi oleh beberapa faktor yaitu faktor kemampuan (ability) dan faktor motivasi (motivation). Hal ini sesuai dengan pendapat David (dalam Prabu, 2005:69) yang merumuskan bahwa human performance adalah fungsi dari ability + motivasi, sedangkan motivasi adalah fungsi dari attitude + situasi sementara ability adalah fungsi knowledge + skill.

Robbins (2001) menyatakan bahwa kinerja sebagai fungsi interaksi antara kemampuan atau ability (A), motivasi atau motivation (M) dan kesempatan atau opportunity $(\mathrm{O})$, yaitu kinerja $=\mathrm{f}(\mathrm{A} \times \mathrm{M} \times \mathrm{O})$. Artinya, kinerja merupakan fungsi dari kemampuan, motivasi dan kesempatan. Dengan demikian, kinerja adalah kesediaan seseorang atau kelompok orang untuk melakukan suatu kegiatan dan menyempurnakannya sesuai dengan tanggung jawabnya dengan hasil seperti yang diharapkan.

Menurut model partner-lawyer (Ivancevich, 1996), kinerja individu pada dasarnya dipengaruhi oleh faktorfaktor harapan mengenai imbalan, dorongan, kemampuan, kebutuhan dan sifat, persepsi terhadap tugas, imbalan internal dan eksternal dan persepsi terhadap tingkat imbalan dan kepuasan kerja. Dengan demikian, kinerja pada dasarnya ditentukan oleh tiga hal, yaitu kemampuan, keinginan dan lingkungan.

Dari berbagai definisi tersebut, pada hakikatnya kinerja merupakan prestasi yang dicapai oleh seseorang atau sekelompok orang dalam melaksanakan tugasnya atau pekerjaannya sesuai dengan standar dan kriteria yang ditetapkan untuk pekerjaan itu. 
Jika ditinjau dari ilmu psikologis, kemampuan (ability) pekerja terdiri dari kemampuan potensi kognisi (IQ) dan kemampuan reality (knowlegde dan skill), artinya pekerja yang memiliki IQ diatas rata-rata (110 -120) dengan pendidikan yang memadai untuk jabatan dan pekerjaannya, ia akan lebih mudah untuk mencapai kinerja yang diharapkan. Motivasi terbentuk dari sikap (attitude) seorang pekerja dalam menghadapi situasi (situation) kerja. Motivasi merupakan kondisi yang menggerakkan diri pekerja yang terarah untuk mencapai tujuan kerja. Sikap mental merupakan kondisi yang mendorong diri pekerja untuk berusahan mencapai prestai kerja (kinerja) secara maksimal, sikap mental yang baik secara psiko-fisik adalah seorang pekerja harus mampu secara fisik dan siap mental, memahami tujuan utama dan target kerja yang akan dicapai, mampu memanfaatkan dan menciptakan situasi kerja.

\section{Pengembangan Hipotesis}

1. $\mathrm{H}_{1}$ : Ada pengaruh secara simultan antara kecerdasan adversity dan motivasi berprestasi terhadap kinerja ditinjau dari etnis pendidik PAUD di Kabupaten Bondowoso

2. $\mathrm{H}_{1}$ : Ada pengaruh secara parsial antara kecerdasan adversity dan motivasi berprestasi terhadap kinerja ditinjau dari etnis pendidik PAUD di Kabupaten Bondowoso

3. $\mathrm{H}_{1}$ : Ada perbedaan tingkat kecerdasan adversity dan motivasi berprestasi berdasarkan kelompok etnis pendidik PAUD di Kabupaten Bondowoso

\section{METODOLOGI PENELITIAN}

\section{Jenis Penelitian}

Penelitian ini merupakan penelitian kuantitatif dengan jenis penelitian berdasarkan waktu pengamatan yaitu crossectional study, karena pengambilan data dilakukan dengan satu kali pengamatan dalam waktu yang sama. Menurut jenis kegunaan dari penelitian, termasuk penelitian penjelasan atau explanatory study karena untuk menjelaskan pengaruh antar variabel teruji dan pengujian hipotesis penelitian yang telah ditetapkan sebelumnya.

\section{Populasi dan Sampel}

Populasi dalam penelitian ini adalah seluruh pendidik PAUD di Kabupaten Bondowoso yang tercatat hingga Bulan Desember 2008 .

Sampel dalam penelitian ini adalah pendidik PAUD peserta pelatihan di Kabupaten Bondowoso dengan pendidikan minimal Diploma 3 (D3) sampai dengan Sarjana (S-1), yang memiliki etnis Jawa atau Madura.

\section{Teknik Pengambilan Sampel dan Jumlah Sampel}

Sampel diambil berdasarkan teknik purposive sampling, mengingat populasi dan sampel telah ditentukan karakteristiknya dan diketahui berdasarkan ciri dan sifatnya. Karena jumlah populasi yang tidak diketahui secara pasti, maka penentuan besar sampel menggunakan rumus sebagai berikut (Bacthiar 2000:269):

$$
n=\frac{z 1-\alpha / 2 P(1-P)}{d^{2}}
$$

Dengan demikian besar sampel minimal yang dibutuhkan dalam penelitian ini agar bisa mewakili populasinya adalah

$\mathrm{n}=(1,960)^{2}(0,25) /(0,105)^{2}$

$\mathrm{n}=87,11$ dibulatkan menjadi 87 sampel

Dalam penelitian ini, besar sampel adalah 94 pendidik PAUD peserta pendidikan dan pelatihan, dan juga didasarkan pada isian instrumen yang dianggap valid dan reliabel.

\section{Variabel Penelitian}

Variabel penelitian dibedakan atas variabel bebas (independent variable) dan variabel tak bebas (dependent variable), variabel bebas adalah tingkat kecerdasan adversity $\left(\mathrm{X}_{1}\right)$, dan motivasi berprestasi $\left(\mathrm{X}_{2}\right)$ sedangkan variabel terikat adalah kinerja $(\mathrm{Y})$.

\section{Instrumen Penelitian}

Penelitian ini menggunakan instrumen penelitian berupa kuesioner dan lembar observasi. Kuesioner merupakan alat pengumpulan data dengan cara memberikan pertanyaan kepada responden berupa tes dan pernyataan. Menggunakan kuesioner merupakan teknik pengumpulan data yang efisien apabila peneliti telah mengetahui secara pasti variabel yang akan diteliti dan apa yang diharapkan dari responden.

\section{HASIL PENELITIAN}

Untuk mengetahui pengaruh antar variabel secara simultan diuji dengan menggunakan uji statistik Anova
2 jalur (two ways Analysis of Varian) dan untuk pengaruh secara parsial dengan menggunakan Anova 1 jalur (one 
way Analysis of Varian) serta untuk melihat perbedaan tingkat adversity dan tingkat motivasi menurut golongan etnis menggunakan Uji Regresi dummy variable (Analysis Regresi Prediktor Nominal) serta uji beda t test sampel bebas.

\section{Uji Hipotesis 1}

Pernyataan hipotesis pertama dalam penelitian ini adalah ada pengaruh secara simultan antara kecerdasan adversity dan motivasi berprestasi terhadap kinerja ditinjau dari etnis pendidik PAUD peserta pelatihan di Kab. Bondowoso. Analisis yang digunakan untuk menguji variabel bebas kecerdasan adversity dan motivasi berprestasi terhadap variabel terikat kinerja menggunakan anova dua jalur atau two-ways anova. Hasil uji anova yang telah dilakukan dapat dilihat pada tabel 1 sebagai berikut.

Tabel 1. Hasil Uji Hipotesis 1 Tanpa Ditinjau dari Kelompok Etnis Tests of Between-Subjects Effects Dependent Variable: Kinerja

\begin{tabular}{|l|r|r|r|r|r|}
\hline \multicolumn{1}{|c|}{ Source } & $\begin{array}{c}\text { Type II Sum } \\
\text { of Squares }\end{array}$ & df & $\begin{array}{c}\text { Mean } \\
\text { Square }\end{array}$ & \multicolumn{1}{c|}{ F } & Sig. \\
\hline Corrected Model & $191.830(\mathrm{a})$ & 62 & 3.094 & 23.979 & .000 \\
Intercept & 2075.228 & 1 & 2075.228 & 16083.015 & .000 \\
AQ & 74.481 & 31 & 2.403 & 18.620 & .000 \\
Motivasi & 19.226 & 11 & 1.748 & 13.545 & .000 \\
AQ * Motivasi & 43.971 & 17 & 2.587 & 20.046 & .000 \\
Error & 4.000 & 31 & .129 & & \\
Total & 3532.000 & 94 & & & \\
Corrected Total & 195.830 & 93 & & & \\
\hline
\end{tabular}

a $\mathrm{R}$ Squared $=.980($ Adjusted $R$ Squared $=.939)$

Sumber : data primer

Hasil Anova dua jalur menunjukkan bahwa terdapat pengaruh langsung antara variabel bebas kecerdasan adversity dan motivasi berprestasi secara simultan terhadap kinerja tanpa melihat kelompok etnis. Tingkat $A Q$ memberikan nilai $F=18.620$ dan Sig 0.000 pada $a=0.05$ artinya ada perbedaan tingkat $A Q$ terhadap tingkat kinerja. Motivasi berprestasi memberikan nilai $\mathrm{F}=13.545$ dan $\mathrm{Sig}=0.000$ pada á $=0.05$ artinya ada perbedaan tingkat motivasi berprestasi terhadap tingkat kinerja. Hasil interaksi antara kecerdasan adversity dan motivasi berprestasi memberikan nilai $F=20.046$ dan Sig 0.000 pada á $=0.05$ hal ini berarti terdapat pengaruh secara bersama atau joint effect antara kecerdasan adversity dan motivasi berprestasi tanpa melihat kelompok etnis terhadap kinerja. Adjusted R Squared sebesar 0.939 atau $93.90 \%$ berarti variabilitas tingkat kinerja yang dapat dijelaskan oleh variabel kecerdasan adversity dan variabel motivasi tanpa melihat kelompok etnis sebesar $93.90 \%$ sisanya atau $6.10 \%$ dipengaruhi oleh faktor lain di luar variabel tersebut di atas.

Hasil Anova dua jalur pada tabel 2 berikut ini menunjukkan bahwa terdapat pengaruh langsung antara variabel bebas kecerdasan adversity dan motivasi berprestasi secara simultan terhadap kinerja ditinjau dari kelompok etnis. Tingkat $A Q$ memberikan nilai $F=$ 20.865 dan Sig 0.000 pada á= 0.05 artinya ada perbedaan tingkat $A Q$ terhadap tingkat kinerja. Motivasi berprestasi memberikan nilai $\mathrm{F}=15.929$ dan $\mathrm{Sig}=0.000$ pada á $=0.05$ artinya ada perbedaan tingkat motivasi berprestasi terhadap tingkat. Kelompok etnis memberikan nilai $F=95.592$ dan Sig 0.000 pada á $=0.05$ artinya ada perbedaan kelompok etnis terhadap tingkat kinerja. Hasil interaksi antara kecerdasan adversity, motivasi berprestasi dan kelompok etnis memberikan nilai $\mathrm{F}=14.411$ dan Sig 0.000 pada á $=0.05$ hal ini berarti terdapat pengaruh secara bersama atau joint effect antara kecerdasan adversity, motivasi berprestasi dan kelompok etnis terhadap kinerja. Adjusted $R$ Squared sebesar 0.937 atau $93.70 \%$ berarti variabilitas tingkat kinerja yang dapat dijelaskan oleh variabel kecerdasan adversity dan variabel motivasi ditinjau dari kelompok etnis sebesar $93.70 \%$ sisanya atau $6.30 \%$ dipengaruhi oleh faktor lain di luar variabel tersebut di atas.

Tabel 2. Hasil Uji Hipotesis 1 Ditinjau dari Kelompok Etnis Tests of Between-Subjects Effects Dependent Variable: Kinerja

\begin{tabular}{|l|r|r|r|r|r|}
\hline \multicolumn{1}{|c|}{ Source } & $\begin{array}{c}\text { Type II Sum } \\
\text { of Squares }\end{array}$ & df & $\begin{array}{c}\text { Mean } \\
\text { Square }\end{array}$ & \multicolumn{1}{c|}{ F } & Sig. \\
\hline Corrected Model & $191.830(a)$ & 63 & 3.045 & 22.837 & .000 \\
Intercept & 1939.834 & 1 & 1939.834 & 14548.756 & .000 \\
AQ & 86.242 & 31 & 2.782 & 20.865 & .000 \\
Motivasi & 23.362 & 11 & 2.124 & 15.929 & .000 \\
Etnis & 12.746 & 1 & 12.746 & 95.592 & .000 \\
AQ * Motivasi * Etnis & 32.664 & 17 & 1.921 & 14.411 & .000 \\
Error & 4.000 & 30 & .133 & & \\
Total & 3532.000 & 94 & & & \\
Corrected Total & 195.830 & 93 & & & \\
\hline
\end{tabular}

a R Squared $=.980($ Adjusted $R$ Squared $=.937)$

Sumber : data primer

\section{Uji Hipotesis 2}

Pernyataan hipotesis kedua dalam penelitian ini adalah ada pengaruh secara parsial antara kecerdasan adversity dan motivasi berprestasi terhadap kinerja ditinjau dari etnis pendidik PAUD peserta pelatihan di Kabupaten Bondowoso. Analisis yang digunakan untuk menguji variabel bebas kecerdasan adversity dan motivasi berprestasi secara parsial terhadap variabel terikat kinerja menggunakan anova satu jalur atau oneway anova. Hasil uji anova yang telah dilakukan dapat dilihat pada tabel sebagai berikut. 


\section{(1) Adversity dan kinerja}

Tabel 3. Hasil uji hipotesis $2 A Q$ dan Kinerja tanpa Ditinjau dari Kelompok Etnis Tests of BetweenSubjects Effects

Dependent Variable: Kinerja

\begin{tabular}{|l|r|r|r|r|r|}
\hline \multicolumn{1}{|c|}{ Source } & $\begin{array}{c}\text { Type I Sum } \\
\text { of Squares }\end{array}$ & df & $\begin{array}{c}\text { Mean } \\
\text { Square }\end{array}$ & \multicolumn{1}{c|}{ F } & Sig. \\
\hline Corrected Model & $127.169(a)$ & 34 & 3.740 & 3.214 & .000 \\
Intercept & 2260.727 & 1 & 2260.727 & 1942.627 & .000 \\
AQ & 127.169 & 34 & 3.740 & 3.214 & .000 \\
Error & 68.661 & 59 & 1.164 & & \\
Total & 3532.000 & 94 & & & \\
Corrected Total & 195.830 & 93 & & & \\
\hline
\end{tabular}

a $R$ Squared $=.649$ (Adjusted $R$ Squared $=.447)$ Sumber : data primer

Hasil Anova satu jalur pada tabel 3 menunjukkan bahwa terdapat pengaruh langsung antara kecerdasan adversity terhadap kinerja tanpa melihat kelompok etnis. Tingkat $A Q$ memberikan nilai $F=3.214$ dan Sig 0.000 pada á $=0.05$ artinya ada perbedaan tingkat $A Q$ terhadap tingkat kinerja. Adjusted R Squared sebesar 0.447 atau $44.70 \%$ berarti variabilitas tingkat kinerja yang dapat dijelaskan oleh variabel kecerdasan adversity dan kelompok etnis sebesar $44.70 \%$ sisanya atau $55.30 \%$ dipengaruhi oleh faktor lain di luar variabel tersebut di atas.

Hasil Anova satu jalur pada tabel 4 berikut ini menunjukkan bahwa terdapat pengaruh langsung antara variabel bebas kecerdasan adversity terhadap kinerja ditinjau dari kelompok etnis. Tingkat $A Q$ memberikan nilai $F=3.903$ dan Sig 0.000 pada á= 0.05 artinya ada perbedaan tingkat $A Q$ terhadap tingkat kinerja. Hasil interaksi antara kecerdasan adversity dan kelompok etnis memberikan nilai $\mathrm{F}=3.369$ dan Sig 0.042 pada á $=0.050$ hal ini berarti terdapat pengaruh secara bersama atau joint effect antara kecerdasan adversity dan kelompok etnis terhadap kinerja. Adjusted $R$ Squared sebesar 0.529 atau $52.90 \%$ berarti variabilitas tingkat kinerja yang dapat dijelaskan oleh variabel kecerdasan adversity dan kelompok etnis sebesar $52.90 \%$ sisanya atau $47.10 \%$ dipengaruhi oleh faktor lain diluar variabel tersebut di atas.

Tabel 4. Hasil Uji Hipotesis 2 AQ dan Kinerja Ditinjau dari Kelompok Etnis Tests of Between-Subjects Effects

Dependent Variable: Kinerja

\begin{tabular}{|l|r|r|r|r|r|}
\hline \multicolumn{1}{|c|}{ Source } & $\begin{array}{c}\text { Type I Sum } \\
\text { of Squares }\end{array}$ & \multicolumn{1}{c|}{ df } & $\begin{array}{c}\text { Mean } \\
\text { Square }\end{array}$ & \multicolumn{1}{c|}{ F } & Sig. \\
\hline Corrected Model & $140.274(a)$ & 37 & 3.791 & 3.822 & .000 \\
Intercept & 2213.373 & 1 & 2213.373 & 2231.080 & .000 \\
AQ & 131.653 & 34 & 3.872 & 3.903 & .000 \\
Etnis & 6.959 & 1 & 6.959 & 7.015 & .010 \\
AQ * Etnis & 6.684 & 2 & 3.342 & 3.369 & .042 \\
Error & 55.556 & 56 & .992 & & \\
Total & 3532.000 & 94 & & & \\
Corrected Total & 195.830 & 93 & & & \\
\hline
\end{tabular}

a $R$ Squared $=.716$ (Adjusted $R$ Squared $=.529)$

Sumber : data primer

\section{(2) Motivasi berprestasi dan kinerja}

Hasil anova satu jalur pada tabel 5 berikut menunjukkan bahwa terdapat pengaruh langsung antara motivasi berprestasi terhadap kinerja tanpa melihat kelompok etnis. Tingkat motivasi berprestasi memberikan nilai $F=3.315$ dan Sig 0.000 pada á= 0.05 artinya ada perbedaan tingkat motivasi terhadap tingkat kinerja. Hasil interaksi antara motivasi berprestasi dan kelompok etnis memberikan nilai $\mathrm{F}=3.624$ dan Sig 0.001 pada á $=0.05$ hal ini berarti terdapat pengaruh secara bersama atau joint effect antara motivasi berprestasi dan kelompok etnis terhadap kinerja. Adjusted R Squared sebesar 0.429 atau $42.90 \%$ berarti variabilitas tingkat kinerja yang dapat dijelaskan oleh variabel motivasi dan kelompok etnis sebesar $42.90 \%$ sisanya atau $57.10 \%$ dipengaruhi oleh faktor lain di luar variabel tersebut di atas.

Tabel 5. Hasil Uji Hipotesis 2 Motivasi Berprestasi dan Kinerja tanpa Ditinjau dari Kelompok Etnis Tests of Between-Subjects Effects

\section{Dependent Variable: Kinerja}

\begin{tabular}{|l|r|r|r|r|r|}
\hline \multicolumn{1}{|c|}{ Source } & $\begin{array}{c}\text { Type I Sum } \\
\text { of Squares }\end{array}$ & df & $\begin{array}{c}\text { Mean } \\
\text { Square }\end{array}$ & \multicolumn{1}{c|}{ F } & Sig. \\
\hline Corrected Model & $72.463(a)$ & 14 & 5.176 & 3.315 & .000 \\
Intercept & 2059.094 & 1 & 2059.094 & 1318.577 & .000 \\
Motivasi & 72.463 & 14 & 5.176 & 3.315 & .000 \\
Error & 123.367 & 79 & 1.562 & & \\
Total & 3532.000 & 94 & & & \\
Corrected Total & 195.830 & 93 & & & \\
\hline
\end{tabular}

a $R$ Squared $=.716$ (Adjusted $R$ Squared $=.529)$

Sumber : data primer

Hasil Anova satu jalur pada tabel 6 berikut ini menunjukkan bahwa terdapat pengaruh langsung antara variabel bebas motivasi berprestasi terhadap kinerja ditinjau dari kelompok etnis. Tingkat motivasi berprestasi memberikan nilai $F=3.069$ dan Sig 0.001 pada á 0.05 artinya ada perbedaan tingkat motivasi terhadap tingkat kinerja. Hasil interaksi antara motivasi berprestasi dan kelompok etnis memberikan nilai $\mathrm{F}=3.624$ dan Sig 0.001 pada á $=0.05$ hal ini berarti terdapat pengaruh secara bersama atau joint effect antara motivasi berprestasi dan kelompok etnis terhadap kinerja. Adjusted $R$ Squared sebesar 0.429 atau $42.90 \%$ berarti variabilitas tingkat kinerja yang dapat dijelaskan oleh variabel motivasi dan kelompok etnis sebesar $42.90 \%$ sisanya atau $57.10 \%$ dipengaruhi oleh faktor lain diluar variabel tersebut diatas. Akan tetapi jika dilihat pengaruh etnis terhadap kinerja 
ternyata tidak signifikan pada á=0.05 karena nilai $\mathrm{F}=0.069$ dan Sig $0.796>0.05$ artinya tidak ada perbedaan kelompok etnis terhadap tingkat kinerja, dengan demikian pengaruh interaksi antara motivasi berprestasi dan kelompok etnis tersebut dikarenakan adanya interaksi semu atau pengaruh semu, jadi faktor etnis disini adalah menjadi variabel mederator yang mempunyai sifat perubah hubungan menjadi lemah atau kuat, oleh karenanya perlu di uji lagi dimana faktor etnis dikontrol, dalam arti diuji secara terpisah antara etnis Jawa dan etnis Madura. Hasil uji Anova satu jalur sebagai berikut.

Tabel 6. Hasil uji hipotesis 2 Motivasi Berprestasi dan Kinerja Ditinjau dari Kelompok Etnis

Tests of Between-Subjects Effects

Dependent Variable: Kinerja

\begin{tabular}{|l|r|r|r|r|r|}
\hline \multicolumn{1}{|c|}{ Source } & $\begin{array}{c}\text { Type I Sum } \\
\text { of Squares }\end{array}$ & df & $\begin{array}{c}\text { Mean } \\
\text { Square }\end{array}$ & \multicolumn{1}{c|}{ F } & Sig. \\
\hline Corrected Model & $112.845(\mathrm{a})$ & 24 & 4.702 & 3.910 & .000 \\
Intercept & 2052.684 & 1 & 2052.684 & 1706.770 & .000 \\
Motivasi & 51.676 & 14 & 3.691 & 3.069 & .001 \\
Etnis & .083 & 1 & .083 & .069 & .794 \\
Motivasi * Etnis & 39.224 & 9 & 4.358 & 3.624 & .001 \\
Error & 82.984 & 69 & 1.203 & & \\
Total & 3532.000 & 94 & & & \\
Corrected Total & 195.830 & 93 & & & \\
\hline
\end{tabular}

a $R$ Squared $=.576$ (Adjusted $R$ Squared $=.429)$

Sumber : data primer

(a) Motivasi berprestasi dan kinerja berdasarkan kelompok etnis Jawa

Hasil uji Anova satu jalur pada tabel 7 menunjukkan nilai $\mathrm{F}=3.316$ dan Sig 0.000 pada á=0.05 yang berarti ada pengaruh tingkat motivasi berprestasi terhadap tingkat kinerja ditinjau dari kelompok etnis Jawa. Nilai Adjusted $R$ Squared sebesar 0.354 atau $35.40 \%$ berarti variabilitas tingkat kinerja yang dapat dijelaskan oleh variabel motivasi sebesar $35.40 \%$ sisanya atau $64.60 \%$ dipengaruhi oleh faktor lain di luar variabel tersebut.

Tabel 7. Hasil Uji Hipotesis 2 Motivasi Berprestasi dan Kinerja Ditinjau dari Kelompok Etnis Jawa Tests of Between-Subjects Effects

Dependent Variable: kinerja

\begin{tabular}{|l|l|c|r|r|r||}
\hline \multicolumn{1}{|c|}{ Source } & $\begin{array}{l}\text { Type I Sum } \\
\text { of Squares }\end{array}$ & df & Mean Square & \multicolumn{1}{c|}{ F } & Sig. \\
\hline Corrected Model & $59.031(\mathrm{a})$ & 13 & 4.541 & 3.316 & .002 \\
\hline Intercept & 1238.722 & 1 & 1238.722 & 904.456 & .000 \\
\hline motivasi & 59.031 & 13 & 4.541 & 3.316 & .002 \\
\hline Error & 57.522 & 42 & 1.370 & & \\
\hline Total & 2193.000 & 56 & & & \\
\hline Corrected Total & 116.554 & 55 & & & \\
\hline
\end{tabular}

a R Squared $=.506$ (Adjusted R Squared $=.354$ ) Sumber : data primer (b) Motivasi berprestasi dan kinerja berdasarkan kelompok etnis Madura

Tabel 8. Hasil Uji Hipotesis 2 Motivasi Berprestasi dan Kinerja Ditinjau dari Kelompok Etnis Madura Tests of Between-Subjects Effects

Dependent Variable: kinerja

\begin{tabular}{|l|r|r|r|r|r|}
\hline \multicolumn{1}{|c|}{ Source } & $\begin{array}{c}\text { Type I Sum } \\
\text { of Squares }\end{array}$ & df & $\begin{array}{c}\text { Mean } \\
\text { Square }\end{array}$ & F & Sig. \\
\hline Corrected Model & $51.406(\mathrm{a})$ & 10 & 5.141 & 5.451 & .000 \\
Intercept & 948.521 & 1 & 948.521 & 1005.811 & .000 \\
motivasi & 51.406 & 10 & 5.141 & 5.451 & .000 \\
Error & 25.462 & 27 & .943 & & \\
Total & 1339.000 & 38 & & & \\
Corrected Total & 76.868 & 37 & & & \\
\hline
\end{tabular}

a $R$ Squared $=.669$ (Adjusted $R$ Squared $=.546)$ Sumber : data primer

Hasil uji Anova satu jalur pada tabel 8 menunjukkan nilai $F=5.451$ dan Sig 0.000 pada á=0.05 yang berarti ada pengaruh tingkat motivasi berprestasi terhadap tingkat kinerja ditinjau dari kelompok etnis Madura. Nilai Adjusted R Squared sebesar 0.546 atau $54.60 \%$ berarti variabilitas tingkat kinerja yang dapat dijelaskan oleh variabel motivasi sebesar $54.60 \%$ sisanya atau $45.40 \%$ dipengaruhi oleh faktor lain di luar variabel tersebut di atas.

\section{Uji Hipotesis 3}

Pernyataan hipotesis ketiga dalam penelitian ini adalah "Ada perbedaan tingkat kecerdasan adversity dan motivasi berprestasi berdasarkan kelompok etnis pendidik PAUD di Kabupaten Bondowoso. Untuk menguji hipotesis ketiga dalam penelitian ini digunakan analisis regresi linier dummy variabel dimana variabel dummy dimaksud adalah kelompok etnis yakni Jawa dinominasikan sebagai angka "0" dan Madura dinominasikan sebagai angka "1", selengkapnya uji regresi linier dummy variabel sebagai berikut.

Persamaan regresi linier

$$
Y=a+b X
$$

$$
a=\frac{\sum Y \cdot \sum X^{2}-\sum X \cdot \sum X Y}{N \cdot \sum X^{2}-\left(\sum X\right)^{2}} \quad b=\frac{N \cdot \sum X Y-\sum X \cdot \sum Y}{N \cdot \sum X^{2}-\left(\sum X\right)^{2}}
$$

Berdasarkan perhitungan pada lampiran didapatkan persamaan sebagai berikut

(1) Persamaan Regresi Linier Dummy Variabel Etnis terhadap Adversity :

$$
Y=120.68519+8.9898148(X)
$$

$\mathrm{F}$ reg $=4.226>\mathrm{F}$ tabel 3.940

pada á $=0.05 \mathrm{db} 1, \mathrm{db} 92$ 
Berdasarkan harga $\mathrm{F}$ reg empirik yang diperoleh dari perhitungan sebesar 4.226 secara signifikan jika dibandingkan dengan $\mathrm{F}$ tabel, karena $\mathrm{F}$ reg $>\mathrm{F}$ tabel, sehingga dengan demikian dapat disimpulkan bahwa persamaan regresi linier dummy tersebut layak digunakan sebagai dasar ramalan pada taraf skor ratarata tingkat kecerdasan adversity pendidik PAUD secara kelompok etnis. Secara lebih khusus dapat diartikan bahwa tingkat kecerdasan adversity kelompok etnis Madura memiliki skor 129.6750 dan kelompok etnis Jawa memiliki skor 120.68519.

(2) Persamaan Regresi Linier Dummy Variabel Etnis terhadap Motivasi Berprestasi

$$
\mathrm{Y}=17-0.7(\mathrm{X})
$$

$\mathrm{F}$ reg $=0.515261<\mathrm{F}$ tabel 3.940

pada $\mathrm{a}=0.05 \mathrm{db} 1, \mathrm{db} 92$

Berdasarkan harga $\mathrm{F}$ reg empirik yang diperoleh dari perhitungan sebesar 0.515261 , jika dibandingkan dengan $\mathrm{F}$ tabel $=3.940$, karena $\mathrm{F}$ reg $<\mathrm{F}$ tabel, sehinggadengan demikian dapat disimpulkan bahwa persamaan regresi linier dummy tersebut tidak layak digunakan sebagai dasar ramalan pada taraf skor ratarata tingkat motivasi berprestasi pendidik PAUD secara kelompok etnis.

(3) Uji beda t test sampel bebas untuk kelompok etnis dengan kecerdasan adversity

Berdasarkan hasil uji t sampel bebas didapat harga $\mathrm{t}=0.203<\mathrm{t}$ tabel 1.98 pada á $=0.05$ dan nilai Sig. $0.840>0.05$ sehingga dengan demikian dapat disimpulkan bahwa tidak ada perbedaan nilai rata-rata skor adversity quotient antara etnis Jawa dan etnis Madura.

(4) Uji beda t test sampel bebas untuk kelompok etnis dengan motivasi berprestasi

Berdasarkan hasil uji t sampel bebas didapat harga $t=2.019>t$ tabel 1.98 pada á $=0.05$ dan nilai Sig. $0.046<0.05$ sehingga dapat disimpulkan bahwa ada perbedaan nilai rata-rata skor motivasi berprestasi antara etnis Jawa dan etnis Madura.

Pengaruh Kecerdasan Adversity dan Motivasi Berprestasi secara Simultan terhadap Kinerja Ditinjau dari Kelompok Etnis.

Hasil analisis uji statistik dengan menggunakan anova dua jalur atau two-ways anova menunjukkan bahwa terdapat pengaruh kecerdasan adversity dan motivasi berprestasi secara simultan terhadap kinerja baik ditinjau dari kelompok etnis maupun tidak ditinjau dari kelompok etnis, artinya, bahwa seseorang yang mempunyai kecerdasan adversity dan motivasi berprestasi yang tinggi akan berpengaruh terhadap tingkat kinerjanya, hal ini terlihat dari harga koefisien determinasi $R^{2}=0.937$ (faktor etnis dimasukkan) dan $R^{2}=0.939$ (faktor etnis tidak dimasukkan), artinya bahwa kecerdasan adversity dan motivasi berprestasi memberikan sumbangan yang sangat efektif pada tingkat kinerja yaitu sebesar $93.70 \%$ dan $93.90 \%$ sedangkan sisanya sebesar $6.30 \%$ dan $6.10 \%$ dipengaruhi oleh variabel lain di luar variabel tersebut.

Kenyataan ini didukung oleh penelitian beberapa ahli mengenai faktor-faktor yang dapat mempengaruhi tingkat kinerja seseorang dikarenakan oleh faktor adversity dan motivasinya. Hal ini dapat dipahami karena di dalam bekerja seseorang akan menghadapi berbagai permasalahan yang kompleks, termasuk bekerja sebagai pendidik PAUD. Kompleksitas permasalahan ini memerlukan ketahanan seseorang sehingga dapat menghadapinya dengan baik dan mencapai kesuksesan, dalam arti berada dalam tingkat kinerja optimal. Ketahanan yang dimaksud di sini adalah ketahanan terhadap masalah dan ketahanan seseorang dalam merespon suatu kesulitan.

Tingkat kinerja yang optimal merupakan kesuksesan bagi seseorang dalam pekerjaan, sehingga dalam mencapai kesuksesan. Stoltz (2006) menyatakan bahwa kesuksesan dipengaruhi oleh bobot kepentingan (motivasinya) terhadap pekerjaan itu dan tingkat kesulitan yang dihadapi dalam pekerjaan itu. Jadi jelaslah bahwa kombinasi dari ke dua variabel di atas yaitu kecerdasan adversity sebagai jawaban dan tanggapan dalam merespon kesulitan dan motivasi secara khusus motivasi untuk selalu berprestasi sebagai keinginan atas kepentingan tertentu dalam pekerjaan guna mencapai kesuksesan dengan meningkatkan kinerja dalam pekerjaannya. Peningkatan kinerja sesungguhnya tidak saja dapat diukur dalam skala hasil yang bisa dikuantifikasi, tetapi ukuran kinerja juga dapat diukur dan ditentukan oleh cara seseorang dalam mengambil suatu keputusan yang menunjukkan kualitas kinerjanya dalam menghadapi dan menyelesaikan masalah atau merespon masalah (Musthofa et al, 2005).

Jika kenyataannya seperti dihasilkan dalam penelitian ini, bahwa dilihat dari sumbangan efektif koefisien determinan $\mathrm{R}^{2}$ hampir sama besarnya 0.937 H" 0.939 ditinjau dari kelompok etnis, maka hal ini sedikit menyimpang dari apa yang dinyatakan oleh Braznitz \& Golberger (dalam Gustiarti, 2002) bahwa respon terhadap stres yang diterjemahkan sebagai respon terhadap kesulitan atau adversity dalam pekerjaan, bergantung dari beberapa faktor salah satunya adalah kebangsaan dan suku bangsa atau ras, karena dari hasil penelitian ini ditemukan bahwa faktor etnis tidak mempengaruhi perubahan koefisien determinasi $R^{2}$. 
Ketidaksesuaian dari teori ini kemungkinan karena adanya hasil interaksi yang signifikan antara faktor etnis dengan variabel kecerdasan adversity atau faktor etnis dengan variabel motivasi berprestasi. Hal ini akan dibahas dalam bahasan selanjutnya yakni pengaruh kecerdasan adversity dan motivasi berprestasi dilihat secara terpisah atau parsial terhadap kinerja ditinjau dari kelompok etnis.

\section{Pengaruh Kecerdasan Adversity dan Motivasi Berprestasi secara parsial terhadap Kinerja Ditinjau dari Kelompok Etnis}

a. Pengaruh kecerdasan adversity terhadap kinerja Hasil analisis uji statistik dengan menggunakan Anova satu jalur atau one-way anova menunjukkan bahwa terdapat pengaruh kecerdasan adversity secara parsial terhadap kinerja baik ditinjau dari kelompok etnis maupun tidak ditinjau dari kelompok etnis. Artinya bahwa seseorang yang mempunyai kecerdasan adversity yang tinggi akan berpengaruh terhadap tingkat kinerjanya, hal ini terlihat dari harga koefisien determinasi $R^{2}=0.447$ (faktor etnis tidak dimasukkan) dan $R^{2}=0.529$ (faktor etnis dimasukkan), artinya bahwa kecerdasan adversity memberikan sumbangan cukup efektif pada tingkat kinerja yaitu sebesar $44.70 \%$ dan $52.90 \%$ sedangkan sisanya sebesar $55.30 \%$ dan $47.10 \%$ dipengaruhi oleh variabel lain di luar variabel penelitian ini.

Seperti halnya pada pembahasan secara simultan kecerdasan adversity ini juga mempengaruhi kinerja secara parsial atau terpisah dari motivasi berprestasi, yang perlu diperhatikan disini adalah nilai koefisien determinan yang berubah dari 0.447 menjadi 0.529 setelah faktor etnis diinteraksikan, meskipun perubahan menambah 0.082 atau $8.20 \%$ saja, tetapi hal ini perlu dicermati bahwa dalam penelitian ini ternyata jika kecerdasan adversity dipisahkan (secara parsial) dari motivasi berprestasi bisa dipengaruhi oleh faktor etnis atau dengan kata lain pengaruh kecerdasan adversity terhadap kinerja dipengaruhi oleh faktor etnis, sehingga faktor etnis disini bisa dianggap sebagai variabel moderator atau variabel pengubah yaitu variabel yang mempengaruhi (memperkuat atau memperlemah) hubungan antara variabel bebas dengan variabel terikat (Sugiyono, 1997).

Jika demikian halnya maka hasil uji secara parsial pengaruh kecerdasan adversity terhadap kinerja ini mendukung teori atau penelitian yang dilakukan oleh Braznitz dan Golberger bahwa respon terhadap stres dalam pekerjaan ditentukan oleh faktor kebangsaan dan suku bangsa atau ras. Jika dilihat dari segi etnis yakni Jawa dan Madura, seorang pendidik PAUD memang berbeda cara pandang dan ketahanan mental dalam hal menghadapi rintangan, hambatan dan persoalanpersoalan pekerjaan sehingga membuat rata-rata lama mereka bekerja berbeda antara etnis Jawa dan etnis Madura, terlepas dari faktor kebutuhan dan kepuasan kerja, hal ini dapat dilihat dari perbedaan rata-rata lama mereka bekerja dalam satu lembaga PAUD, meskipun perbedaan ini tidak signifikan pada Sig $p=0.418>$ á $=0.05$.

Cara pandang yang berbeda dalam merespon suatu kesulitan ini, merupakan keuletan sikap dalam menatap kehidupan, pola asuh yang berbeda dari setiap suku bangsa dan ras juga akan mempengaruhi sikap dan tindakan dalam merespon masalah untuk pengambilan keputusan, sebagaimana dalam penelitian Musthofa et al (2005) bahwa pengambilan keputusan ini melibatkan intuisi. Intuisi adalah persepsi atau keputusan yang cepat dan biasanya diambil tanpa langkah-langkah berdasarkan kesadaran mental dan sering diwarnai oleh situasi subyektif (Drever dalam Musthofa et al, 2005), dan intuisi dibangun oleh ketajaman berpikir secara kognisi, bernalar dan berencana secara strategis. Tidaklah mengherankan jika pola dasar yang diterapkan sebagian besar etnis Madura dalam menyikapi kehidupan untuk lebih ulet dibandiingkan dari etnis Jawa, di sini terlihat adanya pengaruh pola asuh dalam menanamkan daya juang dan pribadi tahan banting atau yang disebutkan dalam buku Stoltz sebagai "adverstunity" yaitu suatu peluang dengan memiliki kemampuan memegang kendali "advertunitas" atau mengubah hambatan menjadi peluang (Stoltz, 2000).

b. Pengaruh motivasi berprestasi terhadap kinerja

Hasil analisis uji statistik dengan menggunakan Anova satu jalur atau one-way anova menunjukkan bahwa terdapat pengaruh motivasi berprestasi secara parsial terhadap kinerja tidak ditinjau dari kelompok etnis. Artinya bahwa seseorang yang mempunyai motivasi yang tinggi akan berpengaruh terhadap tingkat kinerjanya tanpa melihat suku ras atau kelompok etnisnya, hal ini terlihat dari harga koefisien determinasi $\mathrm{R}^{2}=0.258$ (faktor etnis tidak dimasukkan). Akan tetapi ketika faktor etnis dimasukkan ternyata variabel etnis secara nyata tidak berpengaruh pada tingkat kinerja, ditunjukkan nilai $F=7.015$ Sig. $0.794>0.05$, meskipun demikian faktor etnis berpengaruh terhadap kinerja saat berinteraksi dengan variabel motivasi ditunjukkan nilai $\mathrm{F}=3.624$ Sig. $0.001<0.05$. Artinya bahwa pengaruh motivasi berprestasi lebih besar terhadap kinerja ketika berinteraksi atau joint effect dengan faktor etnis daripada ketika motivasi berprestasi tidak berinteraksi dengan faktor etnis atau sebagai main effect. Hal ini 
ditunjukkan dengan nilai $\mathrm{R}^{2}=0.258$ (faktor etnis tidak dimasukkan) dan $\mathrm{R}^{2}=0.429$ (faktor etnis dimasukkan). Artinya sumbangan variabilitas pengaruh motivasi terhadap kinerja adalah $25.80 \%$ meningkat menjadi $42.90 \%$ ketika berinteraksi (joint effect) dengan faktor etnis.

Seperti pada pembahasan pengaruh kecerdasan adversity secara parsial terhadap kinerja, ternyata pengaruh faktor etnis sebagai variabel pengubah cukup besar, sehingga jika dilakukan uji tersendiri secara terpisah antara pengaruh motivasi berprestasi terhadap kinerja berdasarkan etnis Jawa dan etnis Madura secara terpisah maka nilai koefisien determinasi $R^{2}$ tidak sama yakni $\mathrm{R}^{2}=0.354$ (berdasarkan etnis Jawa) dan $R^{2}=0.546$ (berdasarkan etnis Jawa) dengan demikian dapat disimpulkan bahwa faktor etnis dalam pengaruh motivasi berprestasi terhadap tingkat kinerja adalah variabel moderator (variabel pengubah) sehingga perlu dikontrol keberadaannya dalam setiap pengujian hubungan atau pengaruh motivasi berprestasi sebagai variabel tunggal (main effect) terhadap kinerja.

Hal ini berkaitan dengan hasil penelitian yang pernah dilakukan oleh Mc. Clelland di beberapa negara Amerika Serikat, Eropa (Eropa Barat dan Eropa Timur) serta Asia yang menyatakan bahwa kebutuhan akan prestasi ( $n=A c h)$ dipengaruhi oleh pendidikan dan jenis kelamin, pendidikan akan berpengaruh terhadap kesadaran untuk mencapai prestasi lebih tinggi yang merupakan hasil nilai $n=A c h$ tersebut, jenis kelamin berpengaruh secara langsung pada $n=A c h$ ini karena pria lebih memiliki $n=A c h$ ini dibandingkan wanita dengan alasan bahwa wanita lebih takut meraih kesuksesan dengan segala konsekuensinya, pria lebih cenderung kompetitif dan cenderung menfokuskan ambisi mereka untuk menghasikan materi sebagai pendapatan kapital atas kebutuhan mereka, secara keseluruhan pria memberikan nilai lebih pada pencapaian prestasi individu, motivasi secara umum dan senang mengarahkan orang lain, sementara wanita lebih menekankan hubungan interpersonal yang baik, pekerjaan yang nyaman dan menarik, perasaan telah menyelesaikan sesuatu dan pertumbuhan profesional secara layak. Sementara Mc. Clelland tidak secara explisit menjelaskan secara jelas apakah ras, suku dan etnis mempunyai pengaruh yang nyata atas kebutuhan berprestasi ini, meskipun penelitiannya dilakukan pada geografis yang berbeda (Gibson et al, 1996:203).

Hasil penelitian ini membuktikan bahwa faktor etnis memang tidak berpengaruh secara langsung terhadap kinerja (ditunjukkan dengan nilai $F=0.069$ Sig. $0.794>0.05$ ) tetapi berpengaruh ketika berinteraksi dengan motivasi berprestasi, karena faktor etnis merupakan faktor pengubah variabilitas hubungan yakni menjadi variabel moderator.

\section{Perbedaan Kecerdasan Adversity dan Motivasi Berprestasi Ditinjau Dari Kelompok Etnis}

Pada uraian sebelumnya disebutkan tentang pengaruh kecerdasan adversity dan motivasi berprestasi terhadap kinerja ditinjau dari kelompok etnis baik secara simultan maupun parsial, ternyata faktor etnis merupakan variabel pengubah (menguatkan atau melemahkan) atau disebut sebagai variabel moderator. Untuk lebih mengetahui seberapa besar perbedaan skor kecerdasan adversity dan motivasi berprestasi telah diuji dengan menggunakan uji non parametrik regresi linier dummy variabel, dengan etnis sebagai variabel semunya, etnis Jawa bernotasi " 0 " dan etnis Madura bernotasi "1".

Hasil uji regresi linier dummy variabel membentuk persamaan untuk kecerdasan adversity sebagai $Y=$ $120.68519+8.98981 X$ sedangkan persamaan untuk motivasi berprestasi sebagai $Y=17.0-0.7 X$ dimana nilai $F$ reg $=4.226>F$ tabel $=3.94$ pada 2 tailed á $=$ 0.05 yang artinya persamaan regresi tersebut layak digunakan sebagai dasar meramalkan taraf skor berdasarkan kelompok etnis. Sementara untuk motivasi berprestasi karena nilai $F$ reg $=0.515<F$ tabel 3.94 pada 2 tailed á $=0.05$ maka persamaan regresi tersebut tidak layak digunakan sebagai dasar meramalkan taraf skor berdasarkan kelompok etnis.

Persamaan $Y=120.68519+8.98981$ X mempunyai arti bahwa untuk etnis Jawa skor kecerdasan adversitynya adalah 120.68 sedangkan untuk etnis Madura rata-rata skornya kecerdasan adversitynya adalah 129.69 atau 9.01 poin lebih tinggi. Hal ini menggambarkan bahwa etnis Madura mempunyai daya juang, respon terhadap masalah lebih bagus dibandingkan etnis Jawa meskipun skor yang didapatkan dari persamaan regresi tersebut berbeda tetapi perbedaannya tidak signifikan pada taraf 0.05 ditunjukkan dengan nilai t hitung sebesar $0.203<\mathrm{t}$ tabel 1.980 , dan skor tersebut sama-sama masih dalam rentang nilai $A Q$ yang sedang (kelompok campers). Sementara untuk skor motivasi berprestasi berdasarkan kelompok etnis mempunyai perbedaan nilai rata-rata yakni 14.73 untuk etnis Jawa dan 13.11 untuk etnis Madura, dan perbedaan ini signifikan pada 0.05 ditunjukkan dengan nilai t hitung $2.019>$ t tabel 1.980 , dan skor rata-rata tersebut sama-sama tergolong bermotivasi tinggi menurut klasifikasi Mc. Clelland karena di atas nilai 9, dalam arti baik etnis Jawa dan etnis Madura samasama mempunyai keyakinan dan keinginan untuk maju dalam mencapai hasil kinerja secara optimal. 


\section{KESIMPULAN}

\section{Kesimpulan}

Berdasarkan hasil analisis dan pembahasan pada bab terdahulu, maka kesimpulan yang dapat diambil adalah :

1. Terdapat pengaruh yang signifikan antara kecerdasan adversity dan motivasi berprestasi secara simultan terhadap kinerja pendidik PAUD di Kab. Bondowoso baik ditinjau dari kelompok etnis maupun tidak ditinjau dari kelompok etnis. Ditunjukkan dengan nilai koefisien determinan 0.939 dan 0.937 dan nilai Sig $<0.05$. Dengan demikian adanya pengaruh kecerdasan adversity dan motivasi berprestasi secara simultan terhadap kinerja terlepas dari faktor etnis.

2. Terdapat pengaruh yang signifikan antara kecerdasan adversity terhadap kinerja secara parsial ditinjau dari kelompok etnis. Ditunjukkan nilai koefisien diterminan $\mathrm{R}^{2}=0.529$ dan Sig $0.042<0.050$ setelah faktor etnis berinteraksi. Koefisien diterminan $\mathrm{R}^{2}=$ 0.447 dan Sig $0.000<0.05$ jika faktor etnis tidak berinteraksi. Jadi dapat dikatakan bahwa faktor etnis sebagai faktor moderator. Demikian juga terdapat pengaruh yang signifikan antara motivasi berprestasi terhadap kinerja secara parsial ditinjau dari kelompok etnis, ditunjukkan dengan nilai koefisien determinan $R^{2}=0.429$ dan Sig $0.001<0.05$ setelah faktor etnis berinteraksi dan koefisien determinan $R^{2}=0.258$ dan Sig p $0.000<0.05$ jika faktor etnis tidak berinteraksi, Dengan demikian dapat dikatakan bahwa faktor etnis merupakan faktor moderator.

3. Tidak terdapat perbedaan skor rata-rata Adversity Quotient antara etnis Jawa dan etnis Madura, ditunjukkan dengan nilai $t$ hitung $0.203<\mathrm{t}$ tabel 1.980 Sig $0.840>0.050$. Terdapat perbedaan skor ratarata motivasi berprestasi antara etnis Jawa dan etnis Madura. Nilai skor Adversity Quotient dapat diramal- kan dengan menggunakan persamaan regresi linier dummy dengan rumus $Y=120.68519+8.98981 X$, sementara nilai skor motivasi berprestasi tidak dapat diramalkan dengan menggunakan rumus $Y=17.0$ $-0.7 X$ karena nilai $F$ reg $0.515<\mathrm{F}$ tabel 3.90 .

\section{Saran}

Berdasarkan pada hasil penelitian secara keseluruhan dan simpulan yang diperoleh, dapat dikembangkan beberapa saran atau masukkan bagi pihak-pihak yang berkepentingan dengan penelitian ini. Adapun saran-saran yang dapat dikemukakan, sebagai berikut :

1. Dalam rangka peningkatan kinerja pendidik PAUD sebaiknya dilakukan pelatihan yang mengasah adversitynya misalkan dengan outbound training dan team work training

2. Penelitian lanjutan yang berhubungan dengan kecerdasan adversity (Adversity Quotient) dan motivasi berprestasi sebaiknya mengkontrol variabel kelompok etnis, karena dalam penelitian ini faktor etnis merupakan faktor pengubah hubungan atau faktor moderator. Untuk memperkaya hasil penelitian tentang adversity khususnya dan motivasi berprestasi umumnya, sebaiknya faktor karakteristik individu seperti jenis kelamin, umur, jenis pekerjaan, status pernikahan, status sosial, pendapatan dan lain-lain perlu dipertimbangkan, sehingga dapat diketahui faktor apakah yang menjadi variabel moderator atau variabel langsung.

3. Bagi penelitian selanjutnya, menggunakan metode studi cohort akan lebih baik karena bisa mengikuti perubahan-perubahan sikap terutama jika dilakukan dengan retrospektif atau prospective study dan diikuti dengan wawancara mendalam (indept interview) sehingga pada pembahasan penelitian akan lebih tajam dalam mendukung hasil analisis.

\section{DAFTAR PUSTAKA}

Bachtiar, A. (2000). Metodologi penelitian kesehatan. Jakarta: FKM UI.

Balai Pustaka. (1993). Kamus besar bahasa Indonesia. Jakarta

Dharma, A. (1985). Manajemen prestasi kerja. Jakarta: PPM.

Forum Pendidikan Dunia. (2000). Deklarasi Dakkar

Irawan. (1995). Membudayakan etos kerja islami. Jakarta: Gema Insani Press.
Ivancevich, et al. (1996). Organisasi, perilaku, struktur, proses. Edisi kedelapan. Jakarta: Binarupa Aksara.

Gibsons, B., et all. (1996). Performance evaluation, goal setting and feedback. Greenwich: JAI Press.

Gustiarti, L. (2002). Hubungan stres dan kepuasan kerja, Tesis Magíster. Fakultas Kedokteran Program Studi Psikologi. Universitas Sumatera 


\section{Utara. Medan}

Konferensi Dunia. (1990). Pendidikan untuk semua. Jomtien

Mangkunegara, P. (1999). Kebijakan Kinerja Karyawan. Yogyakarta: BPFE.

Mink, T.W.. (1989). Stress and depression. Journal personality and social psychology. 62 (4) 345 355

Mitchell, R., Dweck, C.S. (Editor). (2005). Handbook of competence and motivation. New York.

Mustofa, et al. (2005). Hubungan antara bias keputusan dengan adversity quotient dan anchor dalam pengambilan keputusan. Sosiosains Vol. 18. No.2. Sekolah Pascasarjana Universitas Gadjah Mada. Yogyakarta

Munandar, A.S. (2001). Psikologi industri dan organisasi. Jakarta: UI Press.

Prabu, A. (2005). Manajemen sumber daya manusia perusahaan. Bandung: Remaja Rosdakarya.

Robbins, S.P. (2001). Perilaku organisasi. Jilid 1 dan 2. Edisi Kedelapan. Jakarta: Prenhallindo.
Ruky, A.S. (2001). Performance management system: Panduan praktis untuk merancang dan meraih kinerja prima. Gramedia Pustaka Utama, Jakarta.

Sugiyono. (1997). Perencanaan dan pengawasan. Yogyakarta: BPFE.

Sulistiani, D. (2007). Pengaruh adversity intelligence training terhadap peningkatan sikap kreatif remaja siswa Sekolah Menengah Kejuruan Negeri 5 Surabaya. Tesis Magíster. Universitas Airlangga. Surabaya

Stoltz, P.G. (2000). Adversity quotient : Mengubah hambatan menjadi peluang. Jakarta: Grasindo.

Stoltz, P.G. (2006). Adversity quotient at work : Mengatasi kesulitan di tempat kerja. Batam: Interaksa.

Winardi, J. (2002). Motivasi dan pemotivasian dalam manajemen. Jakarta: Raja Grafindo Persada.

Wikipedia Indonesia. (2009). Kinerja. Diakses tanggal 7 Pebruari 2009 dari http://id.wikipedia.org/wiki/ Kinerja. 